Research Article

\title{
Effect of Different Types of Fly Ash on Properties of Asphalt Mixtures
}

\author{
Katarina Mirkovićc $\left(\mathbb{D},{ }^{1}\right.$ Nikola Tošić $\left(\mathbb{D},{ }^{2}\right.$ and Goran Mladenovićc $\mathbb{D}^{2}$ \\ ${ }^{1}$ University of Montenegro, Faculty of Civil Engineering, Bulevar Džordža Vašingtona b.b., 81000 Podgorica, Montenegro \\ ${ }^{2}$ University of Belgrade, Faculty of Civil Engineering, Bul. kralja Aleksandra 73, 11000 Belgrade, Serbia \\ Correspondence should be addressed to Katarina Mirković; ka-mi@t-com.me
}

Received 14 October 2018; Revised 19 March 2019; Accepted 3 April 2019; Published 5 May 2019

Academic Editor: Faiz U.A. Shaikh

Copyright (c) 2019 Katarina Mirković et al. This is an open access article distributed under the Creative Commons Attribution License, which permits unrestricted use, distribution, and reproduction in any medium, provided the original work is properly cited.

\begin{abstract}
In order to preserve natural resources, the use of waste and alternative materials in the construction and maintenance of roads is increasingly investigated. This paper presents the results of testing wearing course asphalt mixtures (AC 11s SURF 50/70) made with various percentages of fly ash, used as a partial or complete substitute for mineral filler. The properties of fly ash were determined to assess their suitability for use in asphalt mixtures. The experimental research was performed on asphalt samples containing fly ash from three different sources, with $25 \%, 50 \%, 75 \%$, and $100 \%$ of mineral filler substitution. The control mixture was prepared with $100 \%$ of mineral filler. The paper presents the volumetric composition, stability, and flow of asphalt mixtures tested on standard Marshall's samples, water sensitivity, and resistance to permanent deformation. The results of this study indicate that a satisfactory volumetric composition can be achieved by adding fly ash, while the bulk density and voids of the mineral and asphalt mixture generally depend on the type of fly ash and its content. The stability and flow of mixtures with fly ash are favourable compared with the control mixture. The water sensitivity of mixtures with fly ash is generally lower compared with the control mixture and depends on the type and percentage of fly ash. The resistance to permanent deformation of the asphalt mixtures depends on the fly ash type and percentage. The results obtained in this study are an important step towards broader implementation of fly ash in asphalt mixtures.
\end{abstract}

\section{Introduction}

The construction and maintenance of roads requires a large amount of high-quality materials. In order to preserve natural resources, a number of studies have been carried out to prove the usability of different waste and alternative materials in concrete and asphalt pavements such as steel slag, waste rubber, waste polyethylene, recycled concrete, and asphalt aggregate, as well as construction and demolition waste [1-6].

One of the most promising of these materials is fly ash, the by-product of coal combustion which is generated during the production of electricity in thermal power plants. Globally, almost one billion tonnes of fly ash is generated annually [7] and its landfilling represents a significant environmental problem. As a material with pozzolanic activity, fly ash has been widely used in a variety of applications such as concrete, soil improvement, and road construction, namely, for embankments and both unbound and bound subbase and base layers [8-12].

Research on the possibility of its application in asphalt mixtures began around the middle of the previous century, as part of efforts to contribute to sustainable engineering, with the aim of obtaining mixtures of satisfactory properties, reducing the harmful effects of landfilling and preserving natural resources. It has been intensified in the last few decades and has concentrated on two approaches.

One approach is focused on the use of fly ash in bitumen mortar as a substitute for a certain amount of bitumen [13] in order to improve its properties, mainly resistance to permanent deformation, stiffness, viscosity at high temperatures, and temperature sensitivity [13-15].

Sobolev et al. [13] studied the effect of fly ash on the rheological performance of bitumen and mastic using a 
Dynamic Shear Rheometer (DSR). The study included two types of asphalt binders and two types of fly ash, Class C and Class F, as defined in ASTM C618 [16], which differentiates the ashes based on the total content of silica, aluminium, and iron oxide $\left(\mathrm{SiO}_{2}+\mathrm{Al}_{2} \mathrm{O}_{3}+\mathrm{Fe}_{2} \mathrm{O}_{3}\right)$. A microstructural investigation of bitumen with fly ash using a scanning electron microscope (SEM) demonstrated a crack-arresting effect induced by fly ash particles at low temperatures. The investigation of the rheological performance of mastics using DSR confirmed that fly ash can be used as a bitumen extender, replacing up to $15 \%$ of bitumen to improve its resistance to permanent deformation at high temperatures. The best improvement was achieved by adding $15 \%$ of Class $\mathrm{F}$ fly ash or $30 \%$ of Class C fly ash.

Sharma et al. [14] investigated the use of fly ash with different fly ash-to-bitumen (FA/B) ratios in mastics, ranging from 0,6 to 1,2 . The authors found that the softening point, viscosity and complex modulus of mastics were increasing with increasing fly ash content, while the phase angle was decreasing, indicating improved shear resistance with increasing fly ash content. They also found that mastics become less sensitive to the FA/B ratio with increasing temperature.

As representatives of the first approach to the usability of fly ash in asphalt mixtures, these studies share joint conclusions regarding the improvement of mastics properties, possible reduction of the bitumen content, and hence, reduced cost and environmental impact.

The studies which consider the application of fly ash in asphalt mixtures and belong to the second approach, included different classes of fly ash, with varying chemical composition and content of fly ash in the mixture. The main objective of these studies was to determine the optimum amount of mineral filler replacement as well as the impact of fly ash on the volumetric composition, optimum bitumen content, mechanical properties, and performance of asphalt mixtures [13, 14, 17-22].

Sharma et al. [14] found that the Optimum Bitumen Content $(\mathrm{OBC})$ in asphalt mixtures with Class $\mathrm{C}$ fly ash as a filler depends on the filler content and Rigden voids. The OBC decreases with increasing fly ash content. Mistry and Roy [21] came to a similar conclusion for dense bitumen macadam mix with Class $\mathrm{F}$ fly ash. The OBC was slightly decreasing with increasing fly ash content by up to $6 \%$ and that when adding up to the $4 \%$ of fly ash to dense bitumen macadam asphalt mix, the OBC can be reduced by $7.5 \%$ compared with the control mixture with $2 \%$ of hydrated lime as a filer. However, Androic et al. [20] showed an increase in the air void content for fly ash asphalt mixtures compared with a mixture with stone filler, indicating the need for increased bitumen content in mixtures with fly ash.

Mistry and Roy [21] found that for up to $4 \%$ of fly ash, the Marshall stability was lower for the control mixture with $2 \%$ of hydrated lime. The Marshall stability was increasing with fly ash content by up to $6 \%$ of fly ash and then decreasing for higher fly ash contents. Androic et al. [20] reached a similar conclusion, but obtained the highest stability with $3 \%$ of fly ash. However, Kar et al. [17] found that stability was consistently lower for asphalt mixtures with fly ash compared with the control mixture for bitumen contents ranging from $4 \%$ to $7 \%$.

Likitlersuang and Chompoorat [18] found that the ratio of stability and flow of mixtures with a fly ash content ranging from $1 \%$ to $5 \%$ was almost constant and similar to the control mixture, which is confirmed by findings of Mistry and Roy [21].

Sobolev et al. [19] found that asphalt mixtures with fly ash have a higher modulus compared with traditional mixtures with stone dust, which is the result of an increased complex modulus of asphalt mastics with fly ash. Similar findings are reported by Sharma et al. [14].

Sharma et al. [14] found that the Indirect Tensile Strength (ITS) was increasing with fly ash content for all four types of fly ash that were tested. Likitlersuang and Chompoorat [18] also obtained a slight increase of ITS with increasing fly ash content at temperatures of $25^{\circ} \mathrm{C}$ and $55^{\circ} \mathrm{C}$. However, results of $\mathrm{Kar}$ et al. [17] indicate that asphalt mixtures with fly ash have slightly lower ITS compared with the control mixture. Sharma et al. [14] also found that the horizontal tensile strain at failure was largest for mixtures with $7 \%$ of fly ash and that fly ash with high $\mathrm{CaO}$ contents showed the largest strains, indicating higher resistance to low-temperature cracking.

The Indirect Tensile Strength Ratio (ITSR) is a common parameter used to evaluate moisture susceptibility of asphalt mixtures and presents the ratio of ITS of specimens conditioned in water and that of dry specimens. Alternatively, Indian specifications [22] use the Retained Stability (RS) as measure of moisture susceptibility of asphalt mixtures. Sharma et al. [14] found that both ITSR and RS of fly ash asphalt mixtures were equal to or higher than the corresponding values of traditional asphalt mixtures with stone filler. Both ratios were decreasing with increasing fly ash content. The largest improvement in resistance to moisture was obtained with fly ash with the largest $\mathrm{CaO}$ content. This is confirmed by Likitlersuang and Chompoorat [18] who also found an increase in the ITSR for mixtures with fly ash. However, Kar et al. [17] found that RS for mixtures with fly ash is slightly lower for conventional mixture with stone filler but also satisfied requirements according to specifications [22].

Sharma et al. [14] is the only reference presenting the resistance to permanent deformation of asphalt mixtures with fly ash obtained using the static creep test. The authors found that mixtures with fly ash have a favourable rutting resistance compared with the mixture with stone filler. However, the testing was performed at a relatively low temperature of $30^{\circ} \mathrm{C}$ which is not fully representative for rutting resistance, and the static creep test is inferior to simulation tests available nowadays, such as the wheeltracking test.

Based on the literature review, it can be concluded that the addition of fly ash to asphalt mixtures may lead to an improvement in mixture properties and performance. However, findings from previous studies are very often contradictory, leading to the conclusion that the validity of 
some of the presented results may be limited to specific fly ashes used in these studies.

The objective of the study presented in this paper was to investigate the impact of three fly ashes with significantly different chemical compositions on the properties of asphalt mixtures in order to get a more general conclusion regarding the possibility of using fly ash in asphalt mixtures. In addition, the objective was to evaluate the impact of different percentages of substitution of mineral filler, ranging from $25 \%$ to full substitution, on properties and performance of asphalt mixtures, including volumetric composition and resistance to water and permanent deformation.

\section{Materials and Methods}

In this study, a wearing course asphalt mixture with maximum aggregate size of $11 \mathrm{~mm}$ (AC 11s SURF 50/70) was used as the control mixture. The mixture was made of quartz-latite stone aggregate (Quarry "Štitarica," Mojkovac, Montenegro), available in fractions $0 / 4,4 / 8$, and $8 / 11 \mathrm{~mm}$, limestone mineral filler produced by the company "Šišković", Podgorica, Montenegro, and road bitumen B 50/ 70 (Oil Refinery "Pančevo," Serbia). In addition, fly ash from three thermal power plants (TPPs) in the region was used as a partial or full replacement of mineral filler: TPP "Pljevlja"Pljevlja, Montenegro; TPP "Gacko"-Gacko, Bosnia and Herzegovina; and TPP "Kosovo B"-Priština, Kosovo (this designation is without prejudice to positions on status and is in line with UNSCR 1244/1999 and the ICJ opinion on the Kosovo declaration of independence), denoted as fly ash "P" (from TPP "Pljevlja"), "G" (from TPP "Gacko"), and "K" (from TPP "Kosovo B").

2.1. Fly Ash. In order to determine the properties of sampled fly ashes and assess their suitability for use in asphalt mixtures, an extensive testing program was carried out (Table 1), to test chemical, physical, and mechanical properties of fly ash, as well as their environmental impact. Mechanical and physical properties tested included tests used typically for mineral fillers in asphalt mixtures. Testing for the presence of heavy metals, radioactivity, and leaching test was performed in order to assess the potential negative environmental impact of fly ash use.

Table 2 shows the classification of sampled fly ashes according to their chemical composition, while Tables 3 and 4 present the results of the physical and mechanical properties of ashes, which are relevant for assessing the suitability of their use in asphalt mixtures.

The fly ash $\mathrm{P}$ is a Class $\mathrm{F}$ aluminosilicate ash that is pozzolanically active, recommending it for use in the cement industry. A significant percentage of $\mathrm{CaO}(21.08 \%)$, unusual for Class F fly ash, makes it also suitable for use in asphalt mixtures. The smooth texture and spherical shape of the particles make it suitable for embedding [23], but the silicate component gives it hydrophilicity, i.e., weaker affinity with bitumen. In addition, this fly ash is more coarsely graded compared with the standard mineral filler.
A high proportion of $\mathrm{CaO}$ in fly ash $\mathrm{G}(74.44 \%)$ and somewhat less in fly ash $\mathrm{K}(45.98 \%)$ recommend them for use in asphalt mixtures due to improved adhesion of aggregate and bituminous binder, with positive effects on mixture stability. However, fly ashes $\mathrm{G}$ and $\mathrm{K}$ do not meet the requirements of ASTM C 618-19 [16] for Class C in terms of the minimum content of $\mathrm{SiO}_{2}+\mathrm{Al}_{2} \mathrm{O}_{3}+\mathrm{Fe}_{2} \mathrm{O}_{3}$ of $50 \%$. Fly ash $\mathrm{G}$ is an alkaline fly ash with a high content of $\mathrm{CaO}$, whereas fly ash $\mathrm{K}$ has a high sulphate content and is a highly alkaline fly ash without pozzolanic properties.

All three fly ashes meet the requirements of relevant standards related to ecological suitability, presented in Table 1.

To determine the suitability of fly ash for use in asphalt mixtures, the following tests were performed on fly ash samples (Table 4):

(i) Particle size distribution

(ii) Particle density

(iii) Voids of dry compacted filler/fly ash (Rigden voids), which indicate the capacity of the filler/fly ash to hold bitumen

(iv) Increase in the softening point defining the degree of stiffening of the mixture of mineral filler/fly ash and bitumen $(\triangle R \& B)$

(v) Bitumen number $(\mathrm{BN})$ that represents the apparent viscosity of the mixture of mineral filler/fly ash and water

Voids of the dry compacted mineral filler are usually in the range of $28-45 \%$, while for limestone filler, the range is narrower, 30-34\% [24]. All three fly ashes have a higher percentage of Rigden voids than the mineral filler. The void content in fly ash $\mathrm{P}$ is slightly higher than the upper limit for voids in a mineral filler, while fly ashes $K$ and $G$ have substantially higher void contents $(55 \%$ and $59 \%$, respectively), not unusual for fly ash [25], indicating higher absorption of oil components from the bitumen, which will increase stiffness of the mastics and can negatively affect the properties and ageing of bitumen and the bituminous mixture [26].

Increase of the ring and ball softening point $(\triangle R \& B)$ indicates an increase of bitumen 70/100 stiffness to which $37.5 \%(\mathrm{v} / \mathrm{v})$ of specific filler is added. Mineral fillers have an increase in the softening point between $8^{\circ} \mathrm{C}$ and $25^{\circ} \mathrm{C}$, with a most common value of $15^{\circ} \mathrm{C}$.

The increase in $\triangle \mathrm{R} \& \mathrm{~B}$ for fly ash $\mathrm{P}$ is lowest and within the range, while $\Delta R \& B$ of the fly ash $G$ is slightly above the upper limit, and $\triangle \mathrm{R} \& \mathrm{~B}$ of the fly ash $\mathrm{K}$ is significantly outside the $\triangle R \& B$ range for mineral filler. This means that the fly ash $\mathrm{P}$ causes the lowest increase in the mastic (bitumen) stiffness, compared with the other two fly ashes, which is favourable for the longevity of asphalt mixtures and their resistance to cracking.

$\mathrm{BN}$ indicates the amount of water which needs to be added to the fly ash in order to achieve apparent viscosity adequate for the production of asphalt mixtures. Fly ash $\mathrm{G}$ has a $\mathrm{BN}$ similar to mineral filler as a result of high $\mathrm{CaO}$ 
TABle 1: Overview of tests conducted on fly ash specimens.

\begin{tabular}{|c|c|c|c|c|}
\hline $\begin{array}{l}\text { Mechanical } \\
\text { properties/method }\end{array}$ & $\begin{array}{l}\text { Density } \\
\text { EN 1097-7 }\end{array}$ & $\begin{array}{l}\text { Voids in dry compacted } \\
\text { filler (fly ash) } \\
\text { EN 1097-4 }\end{array}$ & $\begin{array}{l}\text { Increase of the ring and } \\
\text { ball softening point } \\
\text { EN 13179-1 }\end{array}$ & $\begin{array}{l}\text { Bitumen number } \\
\text { EN 13179-2 }\end{array}$ \\
\hline $\begin{array}{l}\text { Chemical } \\
\text { composition/method }\end{array}$ & $\begin{array}{c}\mathrm{Na}_{2} \mathrm{O}, \mathrm{MgO}, \mathrm{Al}_{2} \mathrm{O}_{3}, \mathrm{SiO}_{2}, \mathrm{SO}_{3}, \\
\mathrm{~K}_{2} \mathrm{O}, \mathrm{CaO}, \mathrm{TiO}_{2}, \mathrm{Fe}_{2} \mathrm{O}_{3} \\
\mathrm{Gd}_{2} \mathrm{O}_{3}, \mathrm{R} \\
\text { SEM method }\end{array}$ & & & \\
\hline $\begin{array}{l}\text { Ecological } \\
\text { suitability/method }\end{array}$ & $\begin{array}{c}\text { Presence of heavy metals } \\
\text { EN 13656; } A M A-12 ; \\
\text { EN 12457-4 }\end{array}$ & $\begin{array}{c}\text { Radioactivity } \\
\text { Gamma-spectrometric } \\
\text { analysis }\end{array}$ & & $\begin{array}{c}\text { Leaching test } \\
\text { EN 12457-4, EN 12506, EN } \\
\text { 13370, EPA 2007 }\end{array}$ \\
\hline $\begin{array}{l}\text { Content of organic } \\
\text { matters/method }\end{array}$ & $\begin{array}{l}\text { Loss on ignition-LOI } \\
\text { EN } 12879\end{array}$ & & & \\
\hline $\begin{array}{l}\text { Mineral properties/ } \\
\text { method }\end{array}$ & $\begin{array}{l}\text { Determination of amorphous } \\
\text { and crystalline phase contents }\end{array}$ & & & \\
\hline Physical properties & $\begin{array}{c}\text { Colour, shape, and size of } \\
\text { particles, surface texture } \\
\text { SEM method }\end{array}$ & $\begin{array}{l}\text { Gradation } \\
\text { EN 933-10 }\end{array}$ & & \\
\hline
\end{tabular}

TABLE 2: Classification of tested fly ashes by chemical composition.

\begin{tabular}{lcccccc}
\hline Fly ash & \multicolumn{3}{c}{ Chemical composition (\%) } & \multicolumn{2}{c}{ Classification } \\
& $\mathrm{SiO}_{2}$ & $\mathrm{CaO}$ & $\mathrm{SiO}_{2}+\mathrm{Al}_{2} \mathrm{O}_{3}+\mathrm{Fe}_{2} \mathrm{O}_{3}$ & ASTM C 618 & $\begin{array}{c}\text { Mining Institute } \\
\text { Belgrade }\end{array}$ & pH classification \\
\hline $\mathrm{P}$ & 42.83 & 21.08 & $69.78 \sim 70$ & $\mathrm{~F}$ & Calcium-silicate & Aluminosilicate, pozzolanic active \\
$\mathrm{G}$ & 6.04 & 74.44 & $13.85 \ll 50$ & $/$ & Calcium & Alkaline \\
$\mathrm{K}$ & 16.91 & 45.98 & $26.15 \ll 50$ & $/$ & Calcium-silicate & $\begin{array}{c}\text { High sulphate content, highly alkaline, } \\
\text { no pozzolanic properties }\end{array}$ \\
\hline
\end{tabular}

TABle 3: Physical properties of fly ash specimens and standard mineral filler.

\begin{tabular}{|c|c|c|c|c|}
\hline \multirow{2}{*}{ Property } & \multicolumn{3}{|c|}{ Fly ash origin } & \multirow{2}{*}{ Mineral filler } \\
\hline & $\mathrm{P}$ & G & $\mathrm{K}$ & \\
\hline Colour & Grey & Pale dark yellow & Dark yellow & White \\
\hline Particle shape & Mostly spherical & Combined spherical and irregular & Combined spherical and irregular & Angle-shape to prismatic \\
\hline Surface texture & Mostly smooth & Mostly rough & Mostly rough & Mostly rough \\
\hline
\end{tabular}

TABle 4: Mineral filler and fly ash properties.

\begin{tabular}{|c|c|c|c|c|c|c|}
\hline \multirow{2}{*}{ Property } & & \multirow{2}{*}{ Method } & \multirow{2}{*}{ Min. flller Šišković } & \multicolumn{3}{|c|}{ Fly ash } \\
\hline & & & & $\mathrm{P}$ & G & $\mathrm{K}$ \\
\hline \multirow{6}{*}{$\begin{array}{l}\text { Particle size distribution (passing through sieve } \\
\text { opening, } \mathrm{mm} \text { ) (\%) }\end{array}$} & 0.063 & \multirow{6}{*}{ EN 933-10 } & 80.8 & 42 & 44 & 75 \\
\hline & 0.09 & & 90.2 & 57 & 67 & 80 \\
\hline & 0.125 & & 92.8 & 70 & 89 & 84 \\
\hline & 0.25 & & 99.6 & 74 & 91 & 86 \\
\hline & 0.71 & & 100 & 84 & 94 & 92 \\
\hline & 2.0 & & & 100 & 100 & 100 \\
\hline Particle density $\left(\mathrm{mg} / \mathrm{m}^{3}\right)$ & & EN 1097-7 & 2.711 & 2.272 & 2.966 & 2.821 \\
\hline Voids of dry compacted mineral filler (\%) & & EN 1097-4 & 31.5 & 46 & 59 & 55 \\
\hline Increase of the softening point ( $\triangle \mathrm{R} \& \mathrm{~B}$ test $)\left({ }^{\circ} \mathrm{C}\right)$ & & EN 13179-1 & 10.3 & 17.0 & 28.8 & 38.6 \\
\hline Bitumen number (BN) (ml) & & EN 13179-2 & 21 & 45 & 27 & 46 \\
\hline
\end{tabular}

content, while other two fly ashes have substantially higher $\mathrm{BN}$ values.

2.2. Mineral Filler. The mineral filler used in this study represents the standard material used for fillers in asphalt mixtures in the region. The properties of the mineral filler are shown in Table 4 . Figure 1 shows the unified particle size distribution of the mineral filler and three fly ash samples.

Fly ash G completely satisfies EN 13043 particle size distribution requirements for mineral filler, while fly ashes $\mathrm{P}$ and $\mathrm{K}$ have substantially coarser particle size distribution. 


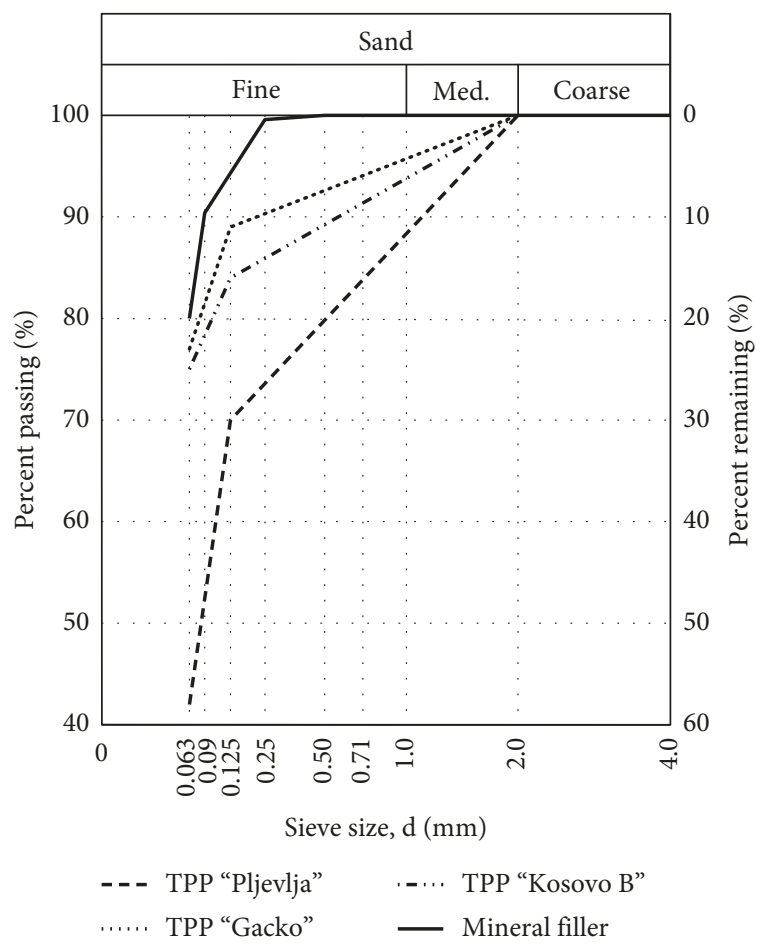

Figure 1: Particle size distribution of mineral filler and three fly ash samples.

2.3. Stone Aggregate. Crushed quartz-latite stone aggregate was used in this study. The particle size distribution and physical properties of the stone aggregate fractions are shown in Figure 2 and Table 5, respectively.

2.4. Bitumen. The basic properties of bitumen B 50/70, used in this study, are shown in Table 6.

2.5. Asphalt Mixtures. One control mixture (with mineral filler only) and 12 mixtures with partial or full replacement of mineral filler with fly ash were tested. The mineral filler participated in the total aggregate matrix with $4 \%$. The replacement of mineral filler with fly ash was $25 \%, 50 \%, 75 \%$, and $100 \%$ which is $1 \%, 2 \%, 3 \%$, and $4 \%$ of the aggregate matrix. The codes of the mixtures used in this study are given in Table 7, with the replacement percentage denoted by the subscript. Table 7 also provides the material composition of the mixtures.

The OBC of $5.6 \%$ for the control mixture AC 11 s was determined using the Marshall method (EN 12697-34) [28]. The same OBC was then applied for mixtures with fly ash.

For all prepared mixtures, the volumetric composition and the physical and mechanical properties were determined by the application of methods shown in Table 8 .

Water sensitivity was tested according to EN 12697-12A [29] and expressed by a ratio (ITSR) of ITS of Marshall specimens, compacted with $2 \times 35$ blows and immersed in water for $70 \mathrm{~h}$ at $40^{\circ} \mathrm{C}$, and the ITS of dry specimens.

Testing of the resistance to permanent deformation of asphalt mixtures was performed on a small device, in air, at a temperature of $60^{\circ} \mathrm{C}$, after 10000 cycles (20,000 passes) in accordance with procedure B of EN 12697-22 [30]. For all 13 mixtures, two slabs $320 \times 260 \times 50 \mathrm{~mm}$ were tested for each mixture. In order to simulate field conditions, prior to the compaction of slabs, asphalt mixtures were conditioned at a temperature of $135^{\circ} \mathrm{C}$ for $4 \mathrm{~h}$.

\section{Results and Discussion}

This section presents the results of experimental tests performed in this study, namely, volumetric composition, stability, and flow of asphalt mixtures, water resistance, and resistance to permanent deformation. Subsequently, the results are discussed in detail for each experimental test.

Taking into consideration the scope and aim of the experimental program, the discussion of the results comprises a descriptive comparative analysis with the aim of assessing the influence of different fly ashes and fly ash percentages on the properties of asphalt mixtures. Such a discussion offers a first step and empirical basis for further, more detailed, experiments and analyses.

3.1. Volumetric Composition, Stability, and Flow of Asphalt Mixtures. The volumetric properties, stability, and flow of asphalt mixtures with fly ash and the control mixture with stone filler are presented in Table 9.

The apparent and bulk densities of mixtures with fly ash depend on the density and content of fly ash. The apparent and bulk densities of $\mathrm{P}$ mixtures decreased with increasing fly ash content, mainly due to the substantially lower density of ash $\mathrm{P}$ compared with the other two fly ashes and mineral filler. Contrary to this, the apparent and bulk densities of $\mathrm{G}$ mixtures increased with increasing fly ash content, while for $\mathrm{K}$ samples, the opposite trend was found. The results for $\mathrm{K}$ mixtures can be explained by the stiffening effect of fly ash $\mathrm{K}$ on the bitumen mastics and its highest $\triangle \mathrm{R} \& \mathrm{~B}$ value (Table 4).

Voids in the mineral aggregate (VMA) in all G mixtures have essentially the same value, within the range of the control mixture. VMA for $\mathrm{P}$ and $\mathrm{K}$ mixtures is higher than for the control mixture and for both groups there is a constant increasing trend with the percentage of replacement, more pronounced for $\mathrm{P}$ mixtures due to their coarser gradation. Air voids in P, G, and $\mathrm{K}$ mixtures follow the same trend within the group as VMA. All G and $\mathrm{K}$ mixtures meet specifications for air voids (below 6.5\%). However, all $\mathrm{P}$ mixtures except $\mathrm{P}_{25}$ have air voids higher that the specified upper limit. The mixture $\mathrm{P}_{100}$ has the largest voids in the asphalt mixture, almost $64 \%$ higher than the control mixture.

The addition of fly ash improves the stability of asphalt mixtures up to $16 \%$ (mixture $\mathrm{P}_{75}$ ). The only exceptions are the $\mathrm{K}_{100}$ mixture which has the lowest stability of all tested mixtures (4\% lower than the control mixture) and the $\mathrm{P}_{50}$ mixture for which stability is equal to the control mixture. The flow of all mixtures with fly ash is smaller for the control mixture, with the $\mathrm{P}$ group having the lowest values. The $\mathrm{P}_{100}$ mixture has the lowest flow deformation, $40 \%$ smaller than 


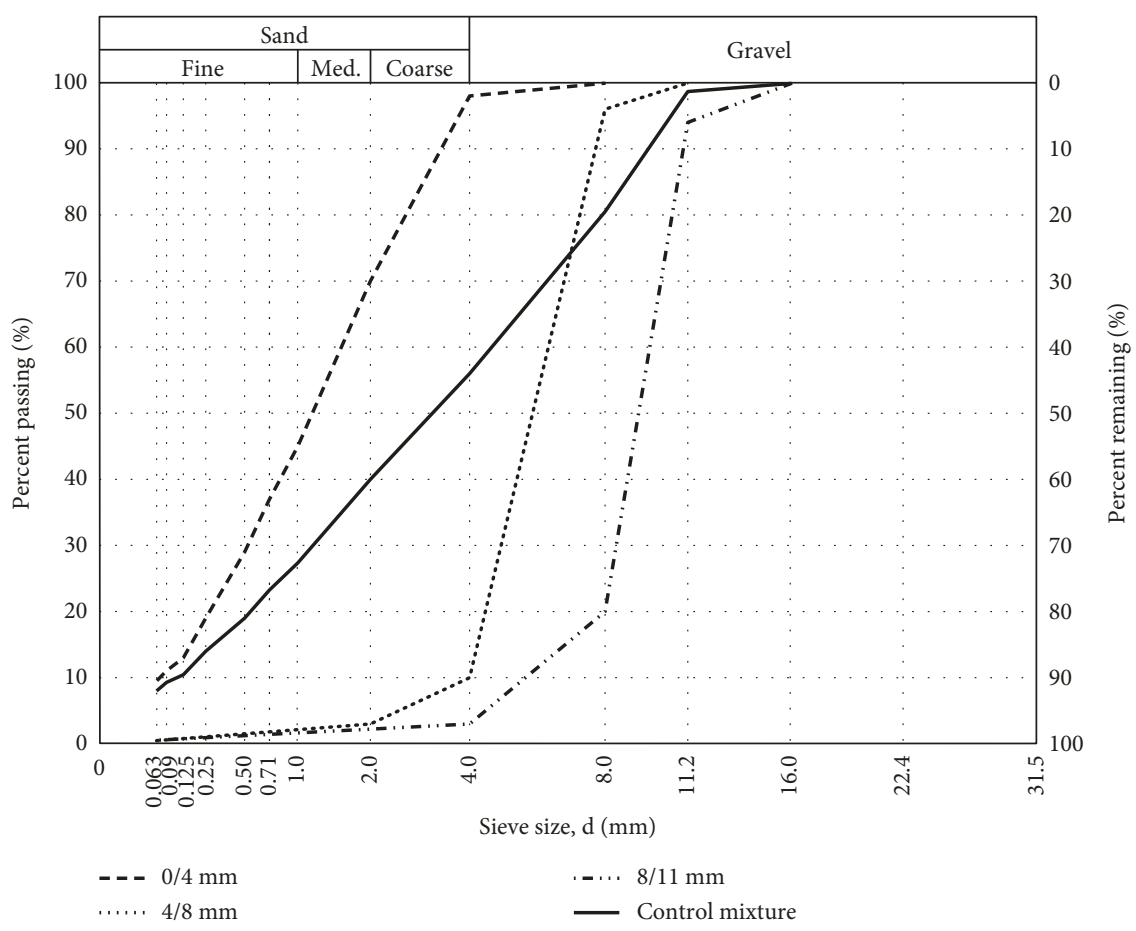

FIgURE 2: Particle size distribution of stone aggregate fractions and control mixture.

TABLE 5: Physical properties of stone aggregate fractions and criteria according to SRPS U.E4.014.

\begin{tabular}{|c|c|c|c|c|c|c|c|}
\hline \multirow{3}{*}{ Property } & \multirow{3}{*}{ Method } & \multicolumn{6}{|c|}{ Stone aggregate fraction $(\mathrm{mm})$} \\
\hline & & \multicolumn{2}{|c|}{$0 / 4$} & \multicolumn{2}{|c|}{$4 / 8$} & \multicolumn{2}{|c|}{$8 / 11$} \\
\hline & & Value & Criterion & Value & Criterion & Value & Criterion \\
\hline Content of particles smaller than $0.09 \mathrm{~mm}(\%)$ & EN 933-1 & 11 & Max 10 & 0 & $\operatorname{Max} 1$ & 0 & Max 1 \\
\hline Density-pycnometer method $\left(\mathrm{Mg} / \mathrm{m}^{3}\right)$ & EN 1097-6 & 2.730 & - & - & - & - & - \\
\hline Density-wire basket method $\left(\mathrm{Mg} / \mathrm{m}^{3}\right)$ & EN 1097-6 & - & - & 2.724 & - & 2.719 & - \\
\hline Sand equivalent $(\%)$ & EN 933-8 & 65.4 & $\min 60$ & - & - & - & - \\
\hline Fineness modulus & SRPS U.E4.014 & 2.64 & $1.95-3.00$ & - & - & - & - \\
\hline Water absorption (\%) & EN 1097-6 & - & - & 0.6 & Max 1.6 & - & - \\
\hline
\end{tabular}

TABLE 6: Bitumen properties.

\begin{tabular}{lcc}
\hline Property & Method & Value \\
\hline Penetration at $25^{\circ} \mathrm{C}(0.01 \mathrm{~mm})$ & EN 1426 & 61 \\
Ring and ball softening point $\left({ }^{\circ} \mathrm{C}\right)$ & EN 1427 & 50.1 \\
Penetration index & EN 12591-A & -0.1 \\
Relative density & EN 15326 & 1.011 \\
\hline
\end{tabular}

the control mixture. The $\mathrm{G}$ and $\mathrm{K}$ mixtures have balanced values within the group, typically $16.7 \%$ lower than the control mixture.

Higher stability and lower flow value of almost all mixtures with fly ash is the result of the stiffening effect that fly ash has on mastic and the mixture, compared with the mineral filler. The effect becomes more pronounced at higher temperatures, which recommends the use of fly ash in warmer climates. Increasing stability and flow reduction is consistent with findings of Androic [20] and Çelik [27] but opposite to findings of Kar et al. [17] who obtained a decrease in Marshall stability and an increase in flow.
3.2. Water Resistance. The ITS test is useful to evaluate the resistance to cracking of asphalt layers, as well as the sensitivity of mixtures to moisture damage. ITSR is determined according to EN 12697-12A [29] as the ratio of ITS of specimens in a water saturated state and specimens in a dry state and is used in this study for the evaluation of moisture susceptibility of all mixtures. The obtained ITS and ITSR values are shown in Table 10. It should be noted that the reported values are averages of three measurements with a very low scatter of results (the coefficient of variation was below $5 \%$ for all mixtures).

The ITS of fly ash asphalt mixtures depends on fly ash type and content. The ITS of all P mixtures is consistently higher than the control mixture (up to $9.3 \%$ ), while for all $\mathrm{K}$ mixtures, the ITS is lower than the control mixture (up to $10.3 \%)$. For $\mathrm{G}$ mixtures, there is a decreasing trend with an increase of fly ash content and for contents below 50\% the ITS is higher than for the control mixture, while for higher replacement percentages, it is lower. This significant difference in ITS results can be related to the chemical 
TABLE 7: Coding and composition of asphalt mixtures.

\begin{tabular}{|c|c|c|c|c|c|c|c|c|c|c|c|c|c|}
\hline \multirow{2}{*}{$\begin{array}{l}\text { Groups of mixtures } \\
\text { Mixture code } \\
\text { Component material }\end{array}$} & \multirow{2}{*}{$\begin{array}{c}\text { Control mix } \\
\mathrm{CM}\end{array}$} & \multicolumn{4}{|c|}{$\mathrm{P}$ group } & \multicolumn{4}{|c|}{ G group } & \multicolumn{4}{|c|}{$\mathrm{K}$ group } \\
\hline & & $\mathrm{P}_{25}$ & $\mathrm{P}_{50}$ & $\mathrm{P}_{75}$ & $\begin{array}{c}\mathrm{P}_{100} \\
\text { Materia }\end{array}$ & $\begin{array}{c}\mathrm{G}_{25} \\
\text { propor }\end{array}$ & $\begin{array}{l}\mathrm{G}_{50} \\
\text { ion by }\end{array}$ & $\begin{array}{c}\mathrm{G}_{75} \\
\text { nass ( }\end{array}$ & $\mathrm{G}_{100}$ & $\mathrm{~K}_{25}$ & $\mathrm{~K}_{50}$ & $\mathrm{~K}_{75}$ & $\mathrm{~K}_{100}$ \\
\hline Mineral filler & 3.78 & 2.83 & 1.89 & 0.94 & - & 2.83 & 1.89 & 0.94 & - & 2.83 & 1.89 & 0.94 & - \\
\hline Fly ash "P" & - & 0.94 & 1.89 & 2.83 & 3.78 & - & - & - & - & - & - & - & - \\
\hline Fly ash “G” & - & - & - & - & - & 0.94 & 1.89 & 2.83 & 3.78 & - & - & - & - \\
\hline Fly ash "K" & - & - & - & - & - & - & - & - & - & 0.94 & 1.89 & 2.83 & 3.78 \\
\hline Stone aggregate $0 / 4 \mathrm{~mm}$ & & & & & & & & & & & & & \\
\hline Stone aggregate $4 / 8 \mathrm{~mm}$ & & & & & & & & & & & & & \\
\hline Stone aggregate $8 / 11 \mathrm{~mm}$ & & & & & & & & & & & & & \\
\hline Bitumen B 50/70 & & & & & & & & & & & & & \\
\hline
\end{tabular}

TABLE 8: Testing of volumetric composition with corresponding methods.

\begin{tabular}{lc}
\hline Property of asphalt mixture & Method \\
\hline $\begin{array}{l}\text { Asphalt specimen density }\left(\mathrm{mg} / \mathrm{m}^{3}\right) \\
\text { Asphalt mixture maximum }\end{array}$ & EN 12697-6-procedure B \\
density $\left(\mathrm{mg} / \mathrm{m}^{3}\right)$ & EN 12697-5-procedure C \\
$\begin{array}{l}\text { Voids in asphalt specimen (\%) } \\
\text { Voids in mineral mixture (\%) }\end{array}$ & EN 12697-8 \\
$\begin{array}{l}\text { Stability }(\mathrm{kN}) \\
\text { Flow }(\mathrm{mm})\end{array}$ & EN 12697-34 \\
\hline
\end{tabular}

composition of fly ashes and their stiffening effect on asphalt mixtures, which can be assessed based on $\triangle \mathrm{R} \& \mathrm{~B}$ values. The observed trends are clearly visible in Figure 3 which plots ITS versus fly ash percentage. The full line represents the control mix value, and the blue, red, and green dashed lines represent linear regression relationships for $\mathrm{P}, \mathrm{G}$, and $\mathrm{K}$ mixtures, respectively.

Fly ash $\mathrm{K}$ is predominantly calcic $(\mathrm{CaO}$ content is $45.98 \%)$ and is characterized by its extremely high $\Delta R \& B$ value $\left(38.6^{\circ} \mathrm{C}\right)$ which indicates its significant stiffening effect of mastic and asphalt mixture, which becomes more brittle, resulting in lower ITS values. Contrary to this, fly ash $\mathrm{P}$ is dominantly silicate $\left(\mathrm{SiO}_{2}\right.$ content is $\left.42.83 \%\right)$ and has the lowest $\triangle \mathrm{R} \& \mathrm{~B}$ value $\left(17.0^{\circ} \mathrm{C}\right)$. This is consistent with findings of Sharma et al. [14] who tested four fly ashes with high $\mathrm{SiO}_{2}$ contents, similar to fly ash $\mathrm{P}$, and found that for all four, the ITS was increasing with increasing fly ash content.

The ITSR indicates moisture susceptibility and should be higher than $70-80 \%$, depending on the specification. Figure 4 plots the ITSR values versus fly ash percentage. Similar to Figure 3, the full line is the control mix value and the blue, red, and green dashed lines are linear regression relationships for $\mathrm{P}, \mathrm{G}$, and $\mathrm{K}$ mixtures, respectively. ITSR for all $P$ and $G$ mixtures is higher than for the control mixture, with an increasing trend with increasing fly ash content, indicating that the use of these fly ashes improves the resistance to moisture of asphalt mixtures. Asphalt mixtures with fly ash $\mathrm{G}$ showed superior ITSR due to the high $\mathrm{CaO}$ content in this fly ash, which helps establish a good bond between bitumen and aggregate, therefore reducing stripping damage. For fly ash $\mathrm{K}$, the opposite trend is observed and ITSR was decreasing with increasing fly ash content.
3.3. Resistance to Permanent Deformation. Rut resistance is an important parameter for design as well as evaluation of performance of asphalt mixtures. To check the rutting resistance of mixtures, simulation tests were performed using the wheel-tracking test according EN 12967-22 [30].

Table 11 presents the rut resistance of mixtures expressed as the proportional rut depth (PRD, ratio of the rut depth and the slab thickness) and the slope of the wheel-tracking deformation curve, i.e., the speed of increasing deformation expressed as the wheel-tracking slope (WTS) from 10000 to 20000 cycles.

The PRD for all mixtures was below 7\%, and for most of mixtures below 5\%, which is considered acceptable and would result in rut resistant asphalt surface courses.

The trends of PRD depend on fly ash type and content. Figure 5 presents the ratios of PRD values of fly ash mixtures, relative to the PRD value for the control mixture. For fly ash $\mathrm{P}$, there is increasing trend of permanent deformation with increasing fly ash content, and for contents below $50 \%$, the PRD of asphalt mixtures is lower than for the control mixture. The opposite, decreasing trend which indicates improved performance, was observed with fly ash G. If fly ash content is below 50\%, PRD is higher, while for higher percentages, it is similar as for the control mixture. The main reason for these trends is particle shape and surface texture. The spherical shape and smooth texture of fly ash $\mathrm{P}$ particles result in increased permanent deformation with increased fly ash content, while the presence of irregular particles and rougher surface texture of fly ash $\mathrm{G}$ result in a decrease of permanent deformation of asphalt mixtures. For fly ash $\mathrm{K}$, mixed trends were observed, but the performance of all mixtures was superior compared to control mixture.

WTS results generally follow the trends for PRD. Figure 6 presents the ratios of WTS values of fly ash mixtures, relative to the WTS value for the control mixture. For P mixtures, the increase in PRD is accelerated with the increase of fly ash percentage, while for the G group of mixtures, there is a decreasing trend. For $\mathrm{K}$ mixtures, the slope of the permanent deformation curve decreases up to $50 \%$ of fly ash content, and then, similar to the mixtures in group $\mathrm{P}$, increases with the addition of larger amounts of fly ash.

This finding for fly ash $\mathrm{P}$ is consistent with findings of Sharma et al. [14], although it should be noted that they used 
TABLE 9: Volumetric properties, stability, and flow of asphalt mixtures.

\begin{tabular}{|c|c|c|c|c|c|c|c|c|}
\hline Mix & $\begin{array}{c}\text { Air voids } \\
(\%)\end{array}$ & $\begin{array}{l}\text { Voids in mineral } \\
\text { aggregate }(\%)\end{array}$ & $\begin{array}{l}\text { Voids filled with } \\
\text { bitumen }(\%)\end{array}$ & $\begin{array}{c}\text { Bulk } \\
\text { density } \\
\left(\mathrm{kg} / \mathrm{m}^{3}\right)\end{array}$ & $\begin{array}{c}\text { Apparent } \\
(\text { maximum }) \\
\text { density }\left(\mathrm{kg} / \mathrm{m}^{3}\right)\end{array}$ & $\begin{array}{l}\text { Stability } \\
(\mathrm{kN})\end{array}$ & $\begin{array}{l}\text { Flow } \\
(\mathrm{mm})\end{array}$ & $\begin{array}{c}\text { Stability/flow } \\
\text { ratio }(\mathrm{kN} / \\
\mathrm{mm})\end{array}$ \\
\hline Control mix & 4.7 & 17.9 & 73.7 & 2371 & 2488 & 10.2 & 4.2 & 2.4 \\
\hline $\mathrm{P}_{25}$ & 5.5 & 18.6 & 70.1 & 2346 & 2484 & 11.3 & 3.3 & 3.4 \\
\hline $\mathrm{P}_{50}$ & 6.7 & 19.6 & 65.7 & 2313 & 2480 & 10.0 & 3.4 & 2.9 \\
\hline $\mathrm{P}_{75}$ & 7.1 & 19.9 & 64.3 & 2300 & 2476 & 11.8 & 3.3 & 3.6 \\
\hline $\mathrm{P}_{100}$ & 7.7 & 20.4 & 62.1 & 2280 & 2471 & 11.2 & 2.5 & 4.5 \\
\hline $\mathrm{G}_{25}$ & 4.6 & 17.8 & 74.3 & 2376 & 2490 & 11.5 & 3.8 & 3.0 \\
\hline $\mathrm{G}_{50}$ & 4.4 & 17.6 & 75.0 & 2382 & 2492 & 10.7 & 3.7 & 2.9 \\
\hline $\mathrm{G}_{75}$ & 4.6 & 17.8 & 74.4 & 2380 & 2494 & 11.0 & 3.5 & 3.1 \\
\hline $\mathrm{G}_{100}$ & 4.4 & 17.7 & 75.0 & 2385 & 2495 & 11.3 & 3.7 & 3.1 \\
\hline $\mathrm{K}_{25}$ & 5.2 & 18.3 & 71.7 & 2360 & 2489 & 11.1 & 3.5 & 3.2 \\
\hline $\mathrm{K}_{50}$ & 5.0 & 18.2 & 72.2 & 2364 & 2490 & 10.4 & 3.6 & 2.9 \\
\hline $\mathrm{K}_{75}$ & 5.7 & 18.8 & 69.5 & 2348 & 2490 & 11.0 & 3.2 & 3.4 \\
\hline $\mathrm{K}_{100}$ & 6.0 & 19.0 & 68.3 & 2341 & 2491 & 9.8 & 3.3 & 3.0 \\
\hline Specification & $3.0-6.5$ & $\mathrm{~N} / \mathrm{A}$ & $65-77$ & & & N/A & N/A & N/A \\
\hline
\end{tabular}

TABLE 10: ITS and ITSR values obtained for the tested asphalt mixtures.

\begin{tabular}{|c|c|c|c|c|c|c|c|c|c|c|c|c|c|}
\hline Groups of mixtures & Control mix & & $\mathrm{Pg}$ & & & & & oup & & & & oup & \\
\hline Mixture code & $\mathrm{CM}$ & $\mathrm{P}_{25}$ & $\mathrm{P}_{50}$ & $\mathrm{P}_{75}$ & $\mathrm{P}_{100}$ & $\mathrm{G}_{25}$ & $\mathrm{G}_{50}$ & $\mathrm{G}_{75}$ & $\mathrm{G}_{100}$ & $\mathrm{~K}_{25}$ & $\mathrm{~K}_{50}$ & $\mathrm{~K}_{75}$ & $\mathrm{~K}_{100}$ \\
\hline ITS (MPa) & 1.07 & 1.14 & 1.11 & 1.17 & 1.09 & 1.15 & 1.11 & 0.99 & 1.01 & 1.00 & 1.03 & 0.96 & 0.97 \\
\hline ITSR (\%) & 72.4 & 74.3 & 76.7 & 75.8 & 77.0 & 78.5 & 82.5 & 81.8 & 82.2 & 74.9 & 69.4 & 64.6 & 65.1 \\
\hline
\end{tabular}

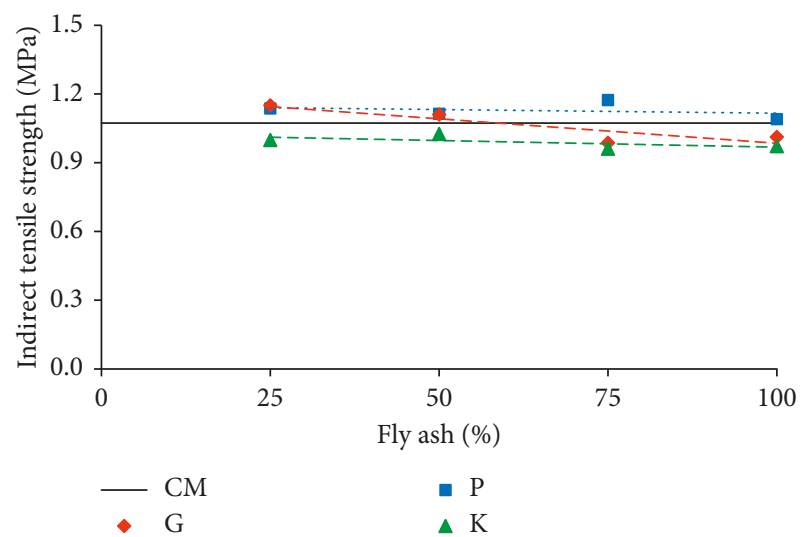

FIGURE 3: ITS results.

a static creep test at $30^{\circ} \mathrm{C}$ and the wheel-tracking test at $60^{\circ} \mathrm{C}$ is considered more representative for determination of rutting resistance of asphalt mixtures.

\section{Conclusions}

This paper presents the results of testing the properties of different types of fly ash in order to determine their influence on properties and performance of asphalt mixtures. Also, the results of the volumetric composition tests are shown, as well as the results for water resistance and resistance to permanent deformation of 12 experimental asphalt mixtures in which the mineral filler was replaced with three types of fly ash of different origin (P, G, and $\mathrm{K}$ ) in four different percentages $(25 \%, 50 \%, 75 \%$, and $100 \%)$.

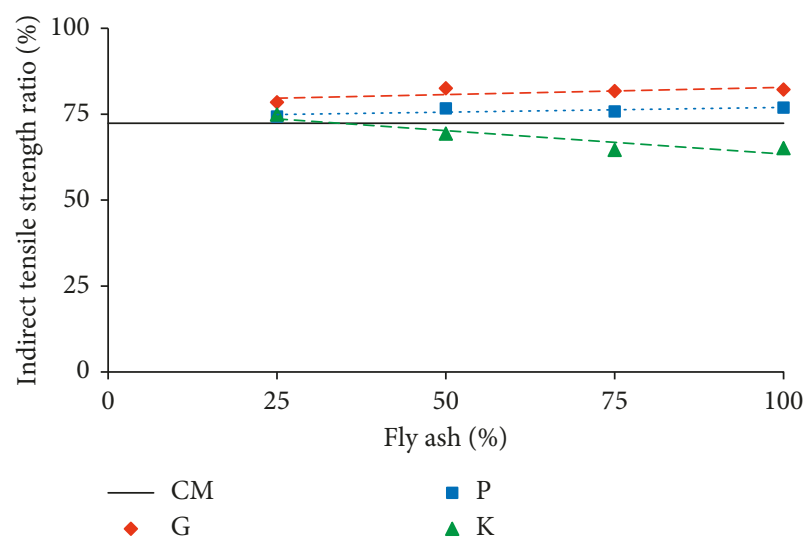

FIGURE 4: ITSR results.

Based on the research results, the following conclusions can be drawn regarding the properties of asphalt mixtures with fly ash:

(i) The apparent and bulk densities of asphalt mixtures with fly ash depend on the density of fly ash and also on the stiffening effect the fly ash has on bitumen mastics.

(ii) By adding all of the three fly ashes, a satisfactory volumetric composition of asphalt mixtures can be achieved, whereby the density and voids in the mineral mixture (VMA) and air voids in asphalt mixtures (AV) generally depend on the fly ash type and content.

(iii) The G group mixtures have slightly lower AV and VMA and highest value of voids filled with 
TABLE 11: PRD and WTS values obtained for the tested asphalt mixtures.

\begin{tabular}{lccccccccccccc}
\hline Groups of mixtures & Control mix & \multicolumn{4}{c}{ P group } & \multicolumn{4}{c}{ G group } & \multicolumn{3}{c}{ group } \\
Mixture code & $\mathrm{CM}$ & $\mathrm{P}_{25}$ & $\mathrm{P}_{50}$ & $\mathrm{P}_{75}$ & $\mathrm{P}_{100}$ & $\mathrm{G}_{25}$ & $\mathrm{G}_{50}$ & $\mathrm{G}_{75}$ & $\mathrm{G}_{100}$ & $\mathrm{~K}_{25}$ & $\mathrm{~K}_{50}$ & $\mathrm{~K}_{75}$ & $\mathrm{~K}_{100}$ \\
PRD (\%) & 4.8 & 3.8 & 4.6 & 6.5 & 5.7 & 6.2 & 6.2 & 4.8 & 4.7 & 4.6 & 3.5 & 3.8 & 4.6 \\
WTS (mm $/ 10^{3}$ cycles) & 0.06 & 0.03 & 0.06 & 0.06 & 0.08 & 0.08 & 0.08 & 0.05 & 0.05 & 0.06 & 0.03 & 0.04 & 0.07 \\
\hline
\end{tabular}

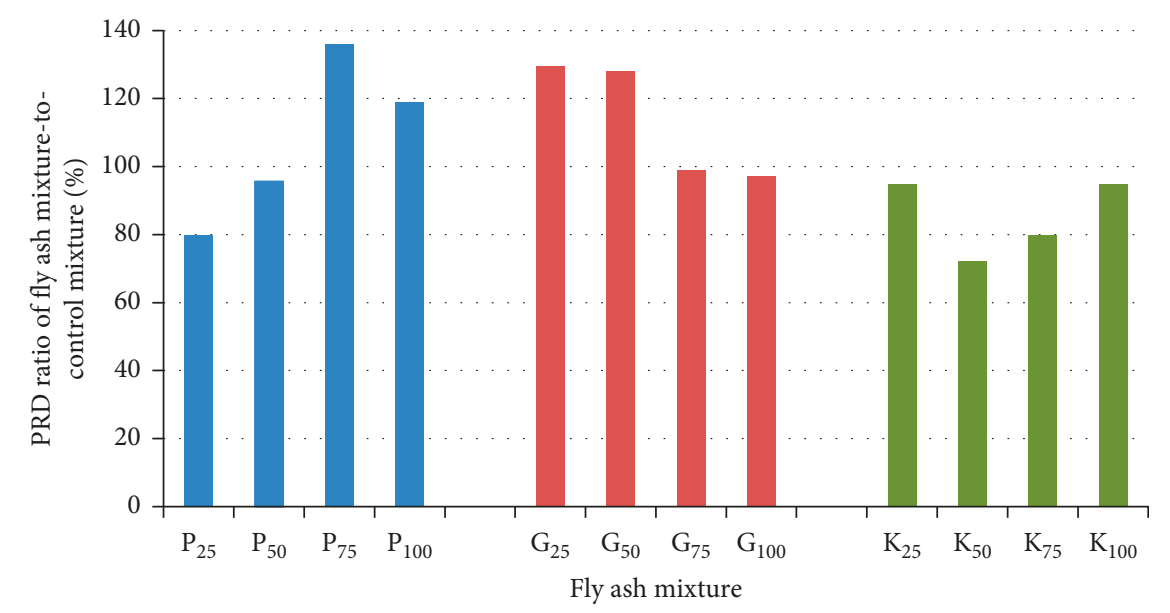

Figure 5: PRD results relative to CM.

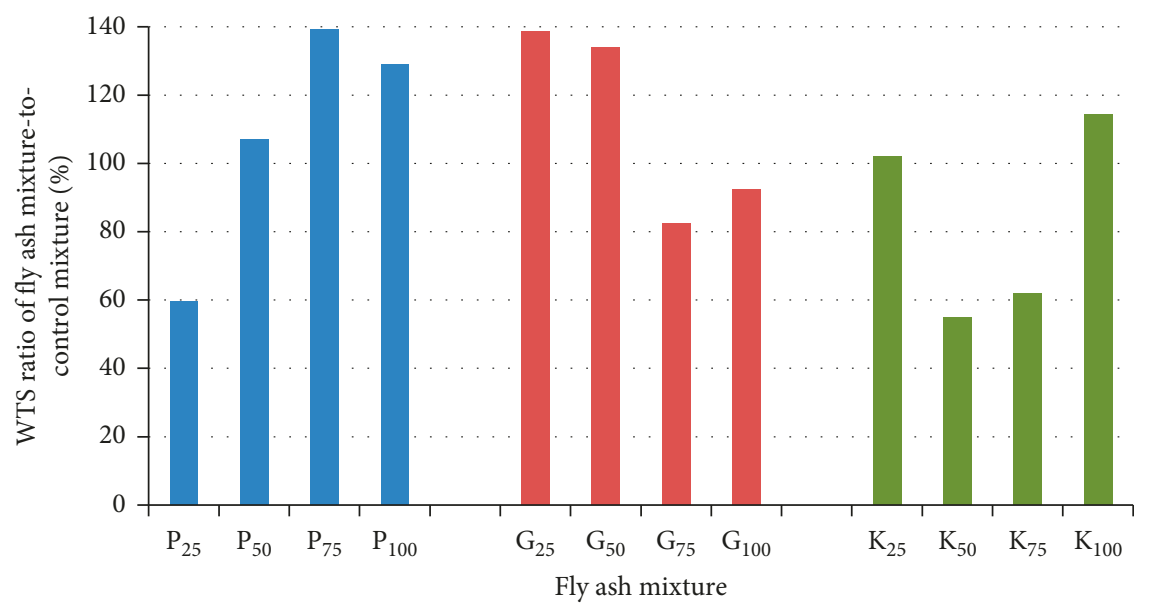

Figure 6: WTS results relative to CM.

bitumen indicating that fly ash $\mathrm{G}$, which has finest particle size distribution, can be used as bitumen extender in asphalt mixtures.

(iv) For fly ashes $\mathrm{P}$ and $\mathrm{K}$, who have coarser gradation, the AV and VMA are higher for control mixture which indicates that bitumen content should be increased.

(v) The addition of fly ash improves stability of asphalt mixtures for up to $16 \%$ and decreases flow for up to $40 \%$. Higher stability and lower flow of almost all mixtures with fly ash are result of substantial stiffening effect of fly ash on asphalt mastics and mixture. The effect becomes more pronounced at higher temperatures, which recommends the use of fly ash as filler in asphalt mixtures in warmer climates. (vi) The ITS of fly ash asphalt mixtures depends on fly ash type and content and ranges within $\pm 10 \%$ of ITS of control mixture. The ITS of all P mixtures is consistently higher than the control mixture (for up to $9.3 \%$ ), while for all $\mathrm{K}$ mixtures, the ITS is lower than the control mixture (up to $10.3 \%$ ). For $\mathrm{G}$ mixtures, there is a decreasing trend with increasing fly ash content, and for contents below $50 \%$, the ITS is higher than for the control mixture, whereas for higher percentages, it is lower. This significant difference in ITS results is related to the chemical composition of fly ashes and their stiffening effect on asphalt mixtures, which can be assessed based on $\triangle R \& B$ values.

(vii) The ITSR for all P and G mixtures is higher than for the control mixture, with increasing trend with 
increase of fly ash content, indicating that use of these fly ashes improves resistance to moisture of asphalt mixtures. Asphalt mixtures with fly ash G showed superior ITSR due to high $\mathrm{CaO}$ content in this fly ash, which helps establish a strong bond between bitumen and aggregate and therefore reducing stripping damage. For fly ash $\mathrm{K}$, the opposite trend is observed and ITSR was decreasing with increase of fly ash content.

(viii) The PRD for all mixtures was below 7\%, and for most of mixtured below $5 \%$, which is considered acceptable and would result in rut-resistant asphalt surface courses. The PRD and WTS mainly depend on particle shape and surface texture. $\mathrm{K}$ mixtures showed superior rut resistance, while for fly ashes $\mathrm{P}$ and $\mathrm{G}$, rutting resistance depends on the fly ash content and is below 5\% for asphalt mixtures with less than $50 \%$ of fly ash P and more than $50 \%$ of fly ash G.

The findings of this study confirm that it is possible to achieve satisfactory properties and performance of asphalt mixtures with partial replacement of mineral filler with fly ash. The optimal replacement percentage depends on type and chemical composition of fly ash, as well as its properties and affinity to bitumen. Fly ash can be used as a bitumen extender or to improve stability, resistance to moisture, and permanent deformation of asphalt mixture as economic solution instead of using polymer modified bitumen and at the same time reduce negative environmental impact.

Future research will include testing of stiffness and development of master curves for asphalt mixtures with fly ash, as well as testing of asphalt mixtures resistance to low temperatures.

\section{Data Availability}

The data used to support the findings of this study are available from the corresponding author upon request.

\section{Conflicts of Interest}

The authors declare that they have no conflicts of interest regarding the publication of this paper.

\section{Acknowledgments}

The experimental testing presented in this paper was performed in the following laboratories: testing of componential materials, preparation of asphalt mixtures, and testing of Marshall samples in the TPA laboratory for quality assurance and innovation Ltd., Čačak, Serbia; testing of ITS, water, and resistance to permanent deformation in the Laboratory for pavement research of the Faculty of Civil Engineering, University of Belgrade, Serbia; SEM of the fly ash samples at the Faculty of Mining and Geology, University of Belgrade, Serbia; and testing of ecological suitability of fly ash at the Center for Ecotoxicological Studies Ltd., Podgorica, Montenegro. The authors are grateful for this support.

\section{References}

[1] M. Prezzi, P. Bandini, J. A. H. Carraro et al., "Use of recyclable materials in sustainable Civil engineering applications," Advances in Civil Engineering, vol. 2011, Article ID 896016, 2 pages, 2011.

[2] M. I. Souliman and A. Eifert, "Mechanistic and economical characteristics of asphalt rubber mixtures," Advances in Civil Engineering, vol. 2016, Article ID 8647801, 6 pages, 2016.

[3] Y. Yang and Y. Cheng, "Preparation and performance of asphalt compound modified with waste crumb rubber and waste polyethylene," Advances in Materials Science and Engineering, vol. 2016, Article ID 5803709, 6 pages, 2016.

[4] M. S. Pourtahmasb and M. R. Karim, "Utilization of recycled concrete aggregates in stone mastic asphalt mixtures," Advances in Materials Science and Engineering, vol. 2014, Article ID 902307, 9 pages, 2014.

[5] M. Mohammadafzali, H. Ali, J. A. Musselman et al., "The effect of aging on the cracking resistance of recycled asphalt," Advances in Civil Engineering, vol. 2017, Article ID 7240462, 7 pages, 2017.

[6] Y. Li, H. Zhou, L. Su et al., "Investigation into the application of construction and demolition waste in urban roads," Advances in Materials Science and Engineering, vol. 2017, Article ID 9510212, 12 pages, 2017.

[7] K. L. Scrivener, V. M. John, and E. M. Gartner, "Eco-efficient cements: potential economically viable solutions for a lowCO2 cement-based materials industry," Cement and Concrete Research, vol. 114, pp. 2-26, 2018.

[8] T. P. Mashifana, F. N. Okonta, and F. Ntuli, "Geotechnical properties and microstructure of lime-fly ashphosphogypsum-stabilized soil," Advances in Civil Engineering, vol. 2018, Article ID 3640868, 9 pages, 2018.

[9] S. Matsumoto, S. Ogata, H. Shimada et al., "Application of coal ash to postmine land for prevention of soil erosion in coal mine in Indonesia: utilization of fly ash and bottom ash," Advances in Materials Science and Engineering, vol. 2016, Article ID 8386598, 8 pages, 2016.

[10] V. Sahu, A. Srivastava, A. K. Misra, and A. K. Sharma, "Stabilization of fly ash and lime sludge composites: assessment of its performance as base course material," Archives of Civil and Mechanical Engineering, vol. 17, no. 3, pp. 475-485, 2017.

[11] S. Mahvash, S. Popez-Querol, and A. Bahadori-Jahromi, "Effect of class F fly ash on fine sand compaction through soil stabilization," Heliyon, vol. 3, no. 3, 2017.

[12] A. M. Rashad, "A brief on high-volume Class F fly ash as cement replacement - a guide for Civil Engineer," International Journal of Sustainable Built Environment, vol. 4, no. 2, pp. 278-306, 2015.

[13] K. Sobolev, I. Flores Vivian, R. Saha, N. M. Wasiuddin, and N. E. Saltibus, "The effect of fly ash on the rheological properties of bituminous materials," Fuel, vol. 116, pp. 471477, 2014.

[14] V. Sharma, S. Chandra, and R. Choudhary, "Characterization of fly ash bituminous concrete mixes," Journal of Materials in Civil Engineering, vol. 22, no. 12, pp. 1209-1216, 2010.

[15] A. Đurekovic and G. Mladenovic, "The performance of bitumen mastics with the addition of fly ash," in Bituminous Mixtures \& Pavements VI, A. Nikolaides, Ed., pp. 115-122, Tailor and Francis Group, London, UK, 2015.

[16] ASTM C 618, Standard Specification for Coal Fly Ash and Raw or Calcined Natural Pozzolan for Use in Concrete, ASTM, West Conshohocken, PA, USA, 2019. 
[17] D. Kar, M. Panda, and J. P. Giri, "Influence of fly ash as a filler in bituminous mixes," Journal of Engineering and Applied Science, vol. 9, no. 6, pp. 895-900, 2014.

[18] S. Likitlersuang and T. Chompoorat, "Laboratory investigation of the performances of cement and fly ash modified asphalt concrete mixtures," International Journal of Pavement Research and Technology, vol. 9, no. 5, pp. 337-344, 2016.

[19] K. Sobolev, I. V. Flores, J. D. Bohler et al., "Application of fly ash in ASHphalt concrete: from challenges to opportunities," in Proceedings of the World of Coal Ash Conference, Session: Cement and Concrete VI, Lexington, KY, USA, April 2013.

[20] I. Androjic, G. Kaludjer, and M. Komljen, "Usage of the fly ash in hot mix asphalt mixes," in Proceedings of the XXVIII International Baltic Road Conference, Vilnius, Lithuania, August 2013.

[21] R. Mistry and T. K. Roy, "Effect of using fly ash as alternative filler in hot mix asphalt," Perspectives in Science, vol. 8, pp. 307-309, 2016.

[22] Ministry of Road Transport and Highways (MoRTH), Specifications for Road and Bridgeworks, Fifth Revision, Indian Roads Congress, New Delhi, India, 2013.

[23] M. Jovanović, A. Mijusković, and A. Šeper, "Mechanical properties of bituminous aggregate mixture BNS 22A prepared with fly ash from power plant Gacko as a filler replacement," in Proceedings of the 15th International Research/ Expert Conference "Trends in the Development of Machinery and Associated Technology," TMT 2011, Prague, Czech Republic, September 2011.

[24] EN 13043, Aggregates for Bituminous Mixtures and Surface Treatments for Roads, Airfields and Other Trafficked Areas, CEN, Brussels, Belgium, 2004.

[25] W. Grabowski, J. Wilanowicz, and T. Sobol, "Structural and functional properties of mineral fillers modified with hydrated lime," in Proceedings of the Sixth International Conference on Maintenance and Rehabilitation of Pavements and Technological Control (MAIREPAV6), Torino, Italy, July 2009.

[26] J. L. M. Voskuilen and J. M. M. Molenar, "Adsorption and desorption of bitumen in toluene on mineral aggregate," in Proceedings of the First Eurasphalt and Eurobitume Congress, Paper 4.078, Strasbourg, France, May 1996.

[27] Ö. Çelik, "Influence of fly ash on the properties of asphalt," Petroleum Science and Technology, vol. 26, no. 13, pp. 15711582, 2008.

[28] EN 12697-34, Bituminous Mixtures-Test Methods for Hot Mix Asphalt-Part 34: Marshall Test, CEN, Brussels, Belgium, 2013.

[29] EN 12697-12: A, Bituminous Mixtures-Test Methods for Hot Mix Asphalt-Part 12: Determination of the Water Sensitivity of Bituminous Specimens, CEN, Brussels, Belgium, 2018.

[30] EN 12697-22, Procedure B, Bituminous Mixtures-Test Methods for Hot Mix Asphalt-Part 22: Wheel Tracking, CEN, Brussels, Belgium, 2007. 


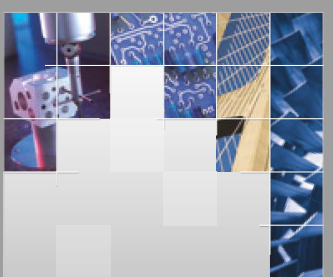

\section{Enfincering}
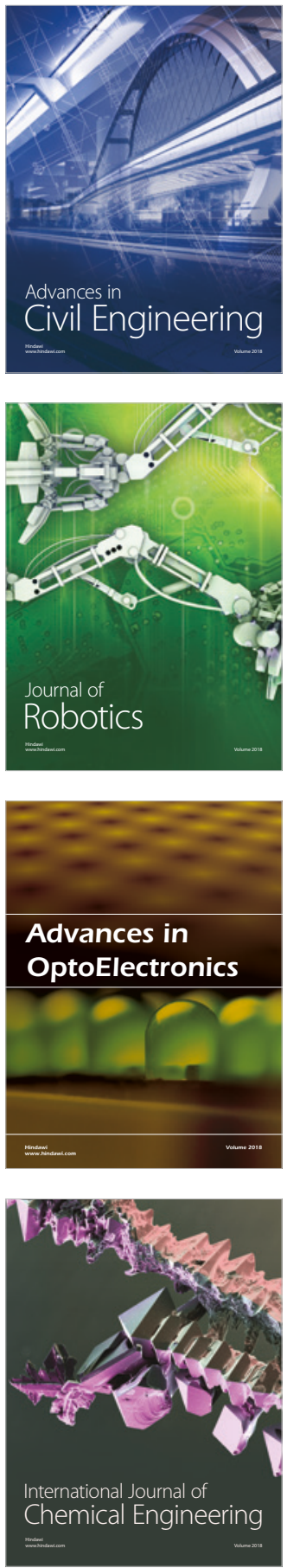

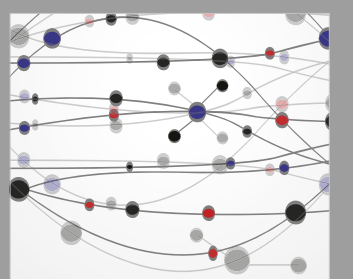

\section{Rotating \\ Machinery}

The Scientific World Journal

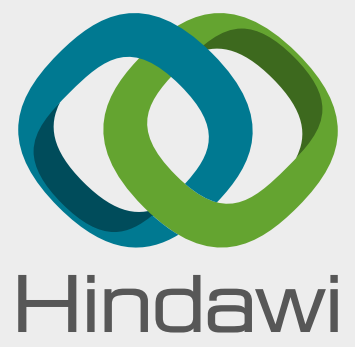

Submit your manuscripts at

www.hindawi.com
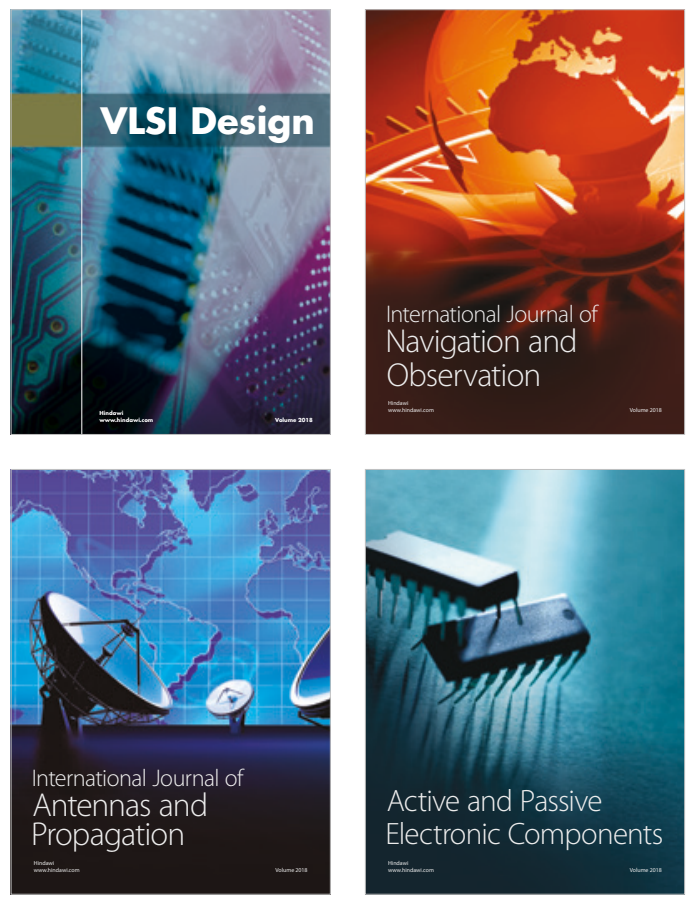
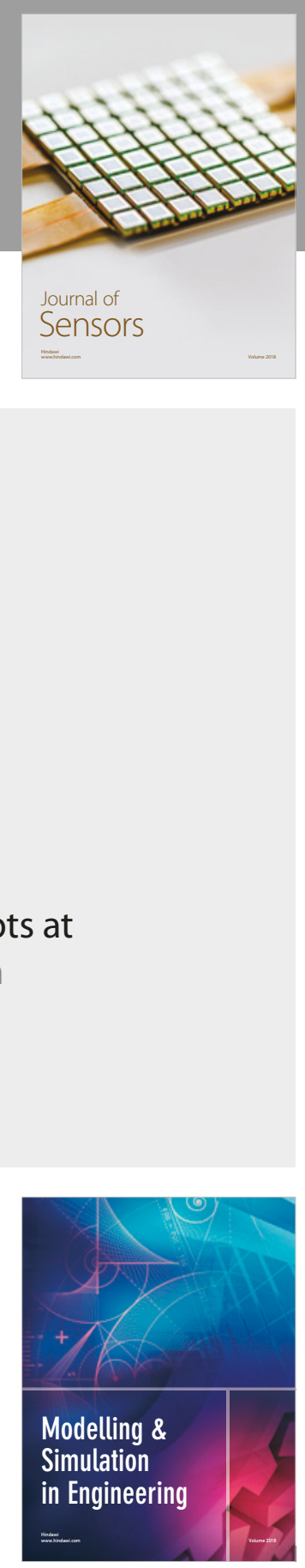

\section{Advances \\ Multimedia}
